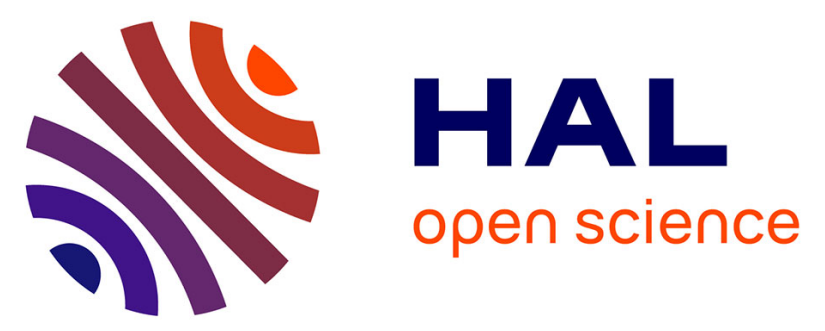

\title{
A Theoretical Approach for Detecting and Anticipating Collaboration Opportunities
}

Ibrahim Koura, Frederick Benaben, Juanqiong Gou

\section{To cite this version:}

Ibrahim Koura, Frederick Benaben, Juanqiong Gou. A Theoretical Approach for Detecting and Anticipating Collaboration Opportunities. APMS 2019 - IFIP WG 5.7 International Conference on Advances in Production Management Systems, Sep 2019, Austin TX, United States. pp.531-538, 10.1007/978-3-030-29996-5_61. hal-02275451

\section{HAL Id: hal-02275451 https://imt-mines-albi.hal.science/hal-02275451}

Submitted on 30 Jan 2020

HAL is a multi-disciplinary open access archive for the deposit and dissemination of scientific research documents, whether they are published or not. The documents may come from teaching and research institutions in France or abroad, or from public or private research centers.
L'archive ouverte pluridisciplinaire HAL, est destinée au dépôt et à la diffusion de documents scientifiques de niveau recherche, publiés ou non, émanant des établissements d'enseignement et de recherche français ou étrangers, des laboratoires publics ou privés.

\section{(c)(1)}

Distributed under a Creative Commons Attribution| 4.0 International License 


\title{
A theoretical approach for detecting and anticipating collaboration opportunities
}

\author{
Ibrahim Koura, Frederick Benaben, Juanqiong Gou \\ IMT Mines Albi, France \\ Beijing Jiaotong University, China \\ \{Ikoura,Frederick.Benaben \}@mines-albi.fr \\ jqgou@bjtu.edu.cn
}

\begin{abstract}
The concept of collaborative networks has been encountered very frequently these days as the reply when trying to adapt and enhance enterprises in this tremendously competitive commercial environments. A lot of knowledge has been gathered for collaborative networks so far, from defining network kinds to levelizing partnerships and also proposing models for partnership developments. But most of these efforts didn't tackle a very vital obstacle which is detecting and predicting collaboration possibilities between enterprises. In this paper, a new enterprise characteristics classification is proposed, which will be used as a profile for characterizing enterprises susceptible to take part in a collaborative network. The proposed detection approach is based on the enterprise characteristics concept as well as collaboration network types. Also a hypothesis to rank the potential partners using KPIs is shown along with the big picture of this approach accompanied by the future work that has to be done.
\end{abstract}

Keywords: Collaborative networks, Enterprise characteristics, Collaboration detection, KPI classification.

\section{$1 \quad$ Introduction}

To catch a transient chance within the market, today's enterprises would rather collaborate with alternative enterprises than invest in resources that may be scarcely used when the chance goes away, although the investment could appear right at the moment of chance arrival. For example Airbus has lately frozen the process of hiring new employees and on the contrary extended the network of its subcontractors. Hence, organizations began to partner up and rely on each other if a benefit is found [1]. However throughout the history, companies were vertically integrated organizations, partnerships were not that easy to form. Nowadays, major changes are taking place in the economy towards more flexible network organizations which are dedicated to help improving the flexibility, ability to quickly setup and maintain partnerships [2], [3]. Working collaboratively could contribute significantly to the success of the business, delivering a number of business benefits including cost savings, increased sales, knowledge transfer and access to new markets, increased capacity and im- 
provements in efficiency and effectiveness. Members of a network will often participate in information-sharing and work together on cost-reduction measures to maximize their competitiveness. It allows the transformation of normal information sharing activity into dynamic relationships that helps all parties in the collaboration network [4], [5]. However, there might be some limitations to the network. Forcing one specific way of style on other parties either because of culture diversity, conflicts in style of working or overshadowing could be a negative aspect if not dealt with correctly. Also timing could be an issue. Gathering information or checking with other parties on each decision can actually slow the process. It also can make things go faster to meet the expectations of the network. Therefore having a balance between those aspects is necessary to have a good collaboration [6].

So how these enterprises could outline, assemble and build their collaborations and how could they optimize their partnership choices and benefit from each other as much as possible. Thus the aim of this research is to propose an approach for suggesting potential collaboration between enterprises using enterprise characterization with the help of network types and concepts. This article will include an explanation for the characterization of an enterprise/organization and examples of collaboration network types. A new hypothesis will be proposed based on an industrial classification criteria which will be used in the approach. Also types of collaboration links are defined along with a ranking hypothesis based on KPI classifications and dimensions.

\section{Collaboration Network types}

In order to understand how an enterprise could be capable for any collaboration and be a part of such network, the type of collaboration networks and properties has to be studied. This section provides an overview of the involved research areas, as found in current literature for collaboration network types examples.

A collaborative network is a network of different entities such as organizations or people that are most of the time not related to each other (geographically, culturally...), in terms of operating environment, culture etc. These entities come together to serve a certain purpose which will benefit all parties in this network [7]. They will often collaborate on commercial ventures such as the development of new products, penetration of new markets and improvement of existing processes, buying and selling finished or non-finished goods and so on.

Moreover, depending on the collaboration goal of each enterprise, there are different types of network examples that can be formed to suffice different types of benefits. Business networks may provide member companies with access to resources that would otherwise be beyond the scope of a single business. Individual businesses can face a number of limitations when trying to compete in global markets, this may include scale and expertise. Through collaboration, businesses can often complement each other and specialize in different areas to compete in markets usually beyond their 
individual reach. Examples of such networks which can be an output of the collaboration process is as follows [4], [7], [8], [9].

- Extended Enterprise - an idea commonly connected to an association in which a dominant industry "broadens" its limits to all or a portion of its providers. An extended enterprise can be seen as a particular case of a VE.

- Virtual Enterprise (VE) - a temporary partnership of industries that meet up to share abilities or center capabilities and assets to react to business openings.

- Virtual Organization (VO) - an idea like a VE, set of autonomous associations that share assets and skills to accomplish a mission/objective, yet that isn't constrained to a partnership revenue driven ventures. A VE is a specific instance of VO.

- Dynamic Virtual Organization - normally alludes to a VO that is built up in a brief span to react to a focused market opportunity, and has a short life cycle, dissolving when the transient reason for the $\mathrm{VO}$ is achieved.

- VO Breeding Environment (VBE) - group of associations and their related supporting organizations that have both the potential and the will to collaborate with one another in a long haul understanding. At the point when a business opportunity is recognized by one part, a subset of these associations can be chosen and subsequently framing a VE or VO.



Fig. 1. Network types example

\section{Approach}

The first step in this approach is to define a profile for each enterprise. There are a lot of characteristics that can define an enterprise, for example number of employees, amount of sales, number of branches and so on. However, due to the lack of literature review in enterprise characterization that can be used in detecting potential collaboration, this article will be using the following characteristics as the principal components of any organization.

1. Performance - can be concerned about liquidity and solvency ratios of a company. Also quality of the product, customer satisfaction and so on. Can be described by revenue, cash fluidity, patrimony, market share, etc. For example, the revenue of company X (mobile manufacturing industry) could be 500,000 euros and the market share would be $15 \%$ from the whole market capacity.

2. Size - can be measured by various criteria like Number of employees, Number of sites, Outsourcing Activities and Existing links with other enterprises. 
3. Type of industry - for example NACE code (industry standard classification system used in the European Union) [10].

4. Type of benefit desired - what are exactly the goals behind such desired collaboration. For example, company $\mathrm{X}$ wants to introduce a new product to the market, thus the goal would be to develop a new process for this new product.

5. Collaboration capability - what can the enterprise offer for such collaboration and what exactly are the tendencies for that.

6. Non tangible characteristics (for example social goals of an enterprise).

These characteristics are going to be used as a profile for any enterprise. This profile will be used in identifying the potential collaboration network. Any subsets of these six characteristics could be a relevant way to characterize organizations. To focus on a proof of concept, in this article we will only consider one specific criteria which is the type of industry (NACE code). This code classifies all industry types into 4 levels (sections, divisions, groups and classes). The criteria for grouping such divisions, groups and classes are discussed in the official European commission document [10]. If we take into account the criteria of divisions, it can be said that if any enterprise that can be identified as one or more industry class, a potential collaboration link can be suggested within the same division. Because two organizations at least within the same division will collaborate together to sell, buy or share something. Normally there could be a lot of different collaboration network types, but if we start with a VE, we can consider the collaborations that would imply similar companies to increase their workforce. So we will first consider that enterprises in the same division are candidates for collaboration. This also doesn't mean that VE can only be considered if the enterprises are in the same division, this is only one possibility of many. Obviously there could be other types, for instance between two divisions with complementary activities in the same group, such as wholesale of food, beverages and tobacco and wholesale of household goods (for example big hyper markets). Also there could be a potential collaboration between two divisions in different sections, such as manufacturing of food products (section C) and fishing (section A). According to this approach, the first and basic step for this enterprise can be: having a potential collaboration with other industry classes within the same group. For example sharing a resource or working together to reach the expectations of the same client. The following example will explain this idea. Enterprise X's industry activity is manufacturing rugs and carpets. So Enterprise $\mathrm{X}$ is considered to be in Section $\mathrm{C}$ (Manufacturing), the class codes for this enterprise is considered to be in the fourth group in division 13 which is 1393 . According to our approach, enterprise X could have a potential collaboration with all the industry types in the same group of class codes 1391, 1392, 1393, $1394,1395,1396$, and 1399.

There are several types of elements that can be exchanged between enterprises. These elements are resources, information, intermediate products (I Product), final products (F Product) and services. These elements are either given, received or shared by an enterprises. Table 1 explains this relation. 
Table 1. Relation between exchange types

\begin{tabular}{|c|c|c|c|c|c|}
\hline & Resource & Information & I Product & F Product & Service \\
\hline Given/Sold by & Owner & Informer/Advisor & Supplier & $\begin{array}{c}\text { Vendor } \\
\text { Endorsee }\end{array}$ & Provider \\
\hline $\begin{array}{c}\text { Received/bought } \\
\text { by }\end{array}$ & Renter & Recipient & Integrator & $\begin{array}{c}\text { Customer } \\
\text { Endorser } \\
\end{array}$ & Receiver \\
\hline Shared & Parties & Parties & Parties & Parties & Parties \\
\hline
\end{tabular}

As shown in table 1, there is a two way direction between 'given/sold by' cells and 'received/bought by' cells due to the nature and type of relation between them. For example if there is a customer then for sure there is a supplier and if there is a renter for a resource then there is an owner, and so on. However in the shared row, the two way direction is within the cell itself as it requires parties with the same role. A potential collaboration within the same division can exist for any exchange types described in table 1.

As discussed earlier in the enterprise characteristics, there were six characteristics that would define any enterprise's profile. If we took two measurements as an example for the first characteristic (performance) like revenue and product quality. An enterprise will be affected by one or both of these measurements depending on which partner joins the collaboration network (Fig 2). If the collaboration partner is an auditing company, this will affect the quality somehow. However if it's an endorser company that can take the final product and introduce it to the market by its name and sell it, then this can affect the revenue. Therefore depending on the desire behind the collaboration, choosing the best partner based on KPIs comes to use.

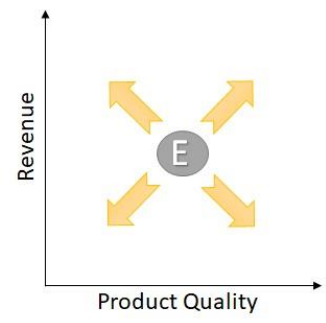

Fig. 2. Effect on enterprise example

The main concern of any enterprise is to manage its resources in a way to achieve a certain goal [9]. In order for an enterprise to test whether it managed to achieve the set of goals or no is to see the results of its KPIs. A lot of KPIs can be stated, but based on [11], five dimensions are listed below which covers all types of KPIs for any industry type.

1. Financial - a measurable value that indicates how well a company is doing regarding generating revenue and profits (ex. Current Ratio).

2. HR - measure the efficiency and effectiveness of human resources processes (ex. Employee Productivity Rate). 
3. Learning \& Growth - measurement of an organization development (ex. R\&D expenses)

4. Product - measurement of a product quality (ex. safety and reliability)

5. Market (customer perspective and sales perspective) - measurement of product effectiveness on customers and market (ex. customer satisfaction and market share percentage)

Each enterprise can have different characteristic measurement within those five dimensions depending on the nature of activity of the enterprise. For example, a plane manufacturer would be more interested to have a very high result of product KPIs (such as quality, safety, reliability...) than HR. However, a university or an educational center would be more interested to improve its learning \& growth KPIs other than focusing on financial KPIs and so on.

Putting in mind the two previous KPI examples, a hypothesis can be proposed regarding the relation between the five KPI dimensions and the exchange types described in table 1. Each relation can have a set of KPI characteristics described in the five KPI dimensions point of view. For example, in a vendor customer relation a customer is interested in a set of KPIs (Fig 3) [12]. If the customer has a priority of improving customer satisfaction rather than increasing the revenue, so it's more convenient to collaborate with a company that has a positive feedback from its customers which in return will affect the company's products in customer's perspective.

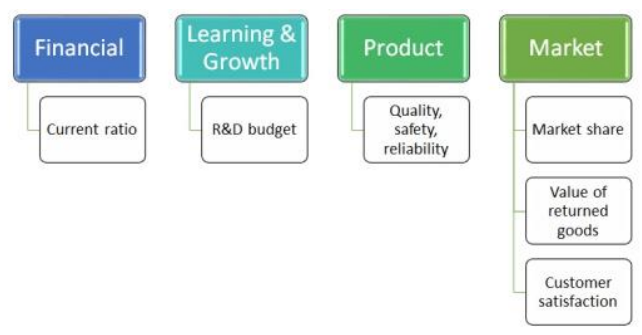

Fig. 3. Vendor KPIs

Of course, one or more of the dimensions could be less of an interest or not even interesting for some enterprises depending on the type of industry and type of relation. For example, for a provider-receiver relationship, the receiver KPIs that a provider might focus on in the financial dimension could be cash flow, current ratio or account payable turnover to be able to estimate the time that the receiver would pay in. For Learning \& growth the KPIs might be average years of service, Accidents or R\&D expense/total expenses. Also, for product it might be usability, repairability or maintainability and for market KPIs it might be customer satisfaction, customer turnover rate or relative market share. However, there might be no interest at all for the HR KPIs as it won't help the provider by any means. Therefore if two or more companies that will act as receivers and are considered to have a potential collaboration with this provider, they will be ranked by this KPI criteria. These were just examples of many KPIs that could be defined for each dimension. Using this hypothesis in a collabora- 
tion network to sell, buy or share helps enterprises to detect the best match to fulfill their goal behind this collaboration.

\section{Conclusion and future work}

The aim of this research is to establish a solution for suggesting potential collaboration between enterprises to help improve their businesses and to benefit from each other as much as possible. This solution can be used by enterprises individually to help find the best suitable collaboration network to serve a potential opportunity or by governments to help proposing better business environments that will improve and develop the economy (Fig 4).

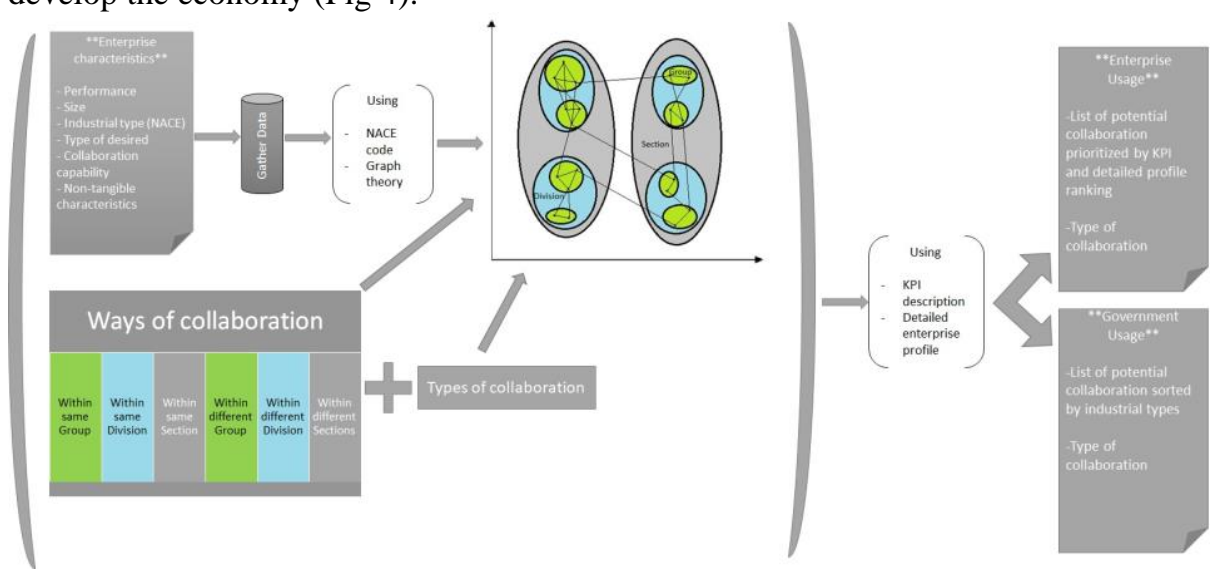

Fig. 4. Big picture

As presented in figure 4, this approach uses enterprise characteristics as a profile to do so. However to focus on a proof of concept, one subset of these characteristics was used which was the NACE code. A new hypothesis was proposed which explains the usage of NACE industry type codes as nodes that will be considered as the first basic level of potential collaboration which can be done between classes within the same group of industry types. This potential collaboration can be subjected to a number of exchange types and links that was also described. Furthermore, the five KPI dimensions were discussed to act as an enterprise profile which will help in detecting the most suitable partner for collaboration of any type. After implementing this hypothesis, the next step of this research would be to develop this model to be able to suggest potential collaboration between different industry types within different divisions and sections and not only within groups. 


\section{References}

[1] U. S. Bititci, V. Martinez, P. Albores, and J. Parung, 'Creating and managing value in collaborative networks', Int. J. Phys. Distrib. Logist. Manag., vol. 34, no. 3/4, pp. 251-268, Mar. 2004.

[2] A. L. Soares, J. P. Sousa, and F. Barbedo, 'Modeling the Structure of Collaborative Networks: Some Contributions', in Processes and Foundations for Virtual Organizations, L. M. Camarinha-Matos and H. Afsarmanesh, Eds. Boston, MA: Springer US, 2004, pp. 23-30.

[3] Luis M. Camarinha-Matos and A. Abreu, 'Performance indicators for collaborative networks based on collaboration benefits', vol. 18, pp. 592-609, Sep. 2007.

[4] J. Bacquet, P. Fatelnig, J. Villasante, and A. Zwegers, 'An outlook of future research needs on networked organizations', Virtual Enterp. Collab. Netw., pp. 17-24, 2004.

[5] T. McLaren, M. Head, and Y. Yuan, 'Supply chain collaboration alternatives: understanding the expected costs and benefits', Internet Res., vol. 12, no. 4, pp. 348-364, Oct. 2002.

[6] Catalina RADU, 'Need and potential risks of strategic alliances for competing successfully', Seria management 13, pp 165-169, June 2010.

[7] Luis M. Camarinha-Matos and H. Afsarmanesh, 'Collaborative networks: a new scientific discipline', Journal of Intelligent Manufacturing, pp. 439-452, Oct. 2005.

[8] L. Camarinha-Matos and H. Afsarmanesh, 'The virtual enterprise concept', working conference on virtual enterprise, pp. 3-14, 1999.

[9] M. T. Martinez, P. Fouletier, K. H. Park, and J. Favrel, 'Virtual enterprise organisation, evolution and control', Int. J. Prod. Econ., vol. 74, no. 1-3, pp. 225-238, Dec. 2001.

[10] Statistical Office of the European Communities, NACE Rev.2: statistical classification of economic activities in the European Community. Luxembourg: Office for Official Publications of the European Communities, 2008.

[11] Kent, Bauer, 'Key Performance Indicators: The Multiple Dimensions', New York vol.14, pp. 62-66, Oct-2004.

[12] 'Characteristics for Qualifying Suppliers, GCP industrial Products'. [Online]. Available: http://www.gcpindustrial.com/blog/characteristics-qualifyingsuppliers, last accessed 2019/03/05. 